\title{
Effect of Silica on Rice Agromorphological Diversity Under Iron Toxicity Conditions in Lowland Rice of Guinea Conakry
}

\author{
Mamadou Laho Barry, PhD Student \\ Université Ouaga 1 Professeur Joseph KI-ZERBO, Ecole Doctorale Sciences \\ et Technologies, Laboratoire Biosciences, Equipe Génétique et \\ Amélioration des Plantes (EGAP), Ouaga, Burkina Faso \\ Institut de Recherche Agronomique de Guinée (IRAG), Guinée Conakry \\ Nerbewende Sawadogo, PhD, \\ Mahamadi Hamed Ouedraogo, PhD \\ Kiswendsida Romaric Nanema, PhD
}

Université Ouaga 1 Professeur Joseph KI-ZERBO, Ecole Doctorale Sciences et Technologies, Laboratoire Biosciences, Equipe Génétique et

Amélioration des Plantes (EGAP), Ouaga, Burkina Faso

\section{Mamadou Billo Barry, PhD}

Institut de Recherche Agronomique de Guinée (IRAG), Guinée Conakry

\section{Pauline Bationo-Kando, PhD \\ Mahamadou Sawadogo, PhD}

Université Ouaga 1 Professeur Joseph KI-ZERBO, Ecole Doctorale Sciences et Technologies, Laboratoire Biosciences, Equipe Génétique et Amélioration des Plantes (EGAP), Ouaga, Burkina Faso

\section{Doi: 10.19044/esj.2019.v15n3p118 ～URL:http://dx.doi.org/10.19044/esj.2019.v15n3p118}

\begin{abstract}
Rice is the second most important cereal in West Africa and is an essential element in the diet of the population. However, iron toxicity is one of the major edaphic constraints in lowland rice cultivation. The large amount of ferrous ions in solution causes an imbalance in nutrients involving a nutritional disorder affecting the growth of crops including rice. The present study conducted in 2014 in Guinea Conakry in the lowlands of the Kilissi Agronomic Research Station aimed to evaluate the effect of silica on reducing of the effect of iron toxicity in rice. Thus, rice varieties were evaluated according to a split plot device with three (3) randomized replications for two factors (rice varieties and silica doses) and three (3) silica treatments (D0 g, D120 g and D240 g). The results showed a significant effect of silica on most agronomic parameters of the rice varieties tested. The D240 g dose gave the
\end{abstract}


best yields of up to $6.9 \mathrm{t} / \mathrm{h}$. Seventeen (17) varieties exhibited good agronomic characteristics of yield, cycle, and weight of 1000 grains. In addition, the study reveals a possibility of reducing the effect of iron toxicity in lowlands in Guinea by the combined use of silica and rice varieties resistant or tolerant to iron. The genetic variability observed with certain tolerant varieties with ferrous toxicity like CK4 could be exploited in our national rice breeding program.

Keywords: Oryza glaberrima, ferrous ions, Genetic diversity, resistant, Guinea Conakry

\section{Introduction}

Rice (Oryza sativa L.) is one of the most widely consumed cereals in the world (CTA, 2013). According to FAOSTAT (2011), more than 479.2 million tons of rice is produced per year worldwide for an average human consumption of 468 million tons of rice. Unfortunately, this world production is more than $90 \%$ assured by Asia, which is 675 million tons. It is the major source of nutrition in most of the South Asian countries (Kuri et al, 2014).

Africa produces only 29 million tons representing $4 \%$ with an annual consumption per inhabitant of $40 \mathrm{~kg}$ (CIRAD, 2010). For Africa Rice (2013), more than 200 million hectares of arable land can be used for rice cultivation. But it only exploits 9.7 million hectares for rice. Africa is therefore the continent with the most resources for rice development (Futakuchi et al., 2011).

In West Africa, rice is an essential element in the diet of the population. It ranks $2^{\text {nd }}$ among the most important cereal crops. Its average per inhabitant consumption increased from $13 \mathrm{~kg}$ in the 1960s to $18 \mathrm{~kg}$ in 2009 (IFDC, 2011), an increase of $38.5 \%$. This consumption depends largely on imports. Previous studies have already highlighted the influence of factors such as fertilizer and climate zone on the variation in the productivity of rice varieties such as NERICA (Worou et al., 2017) or the suitability for parboiling of rice varieties (Houssou et al., 2016).

In the Republic of Guinea, rice is a strategic commodity for the government and the people because its availability, accessibility and stability depend on the country's food security and social peace (Barry, 2006). Cultivated on nearly 520,000 ha, rice alone accounts for $65 \%$ of cereal supplies (FAO, 2007). Annual production has increased considerably in recent decades, from 420000 tons in 1991 to 1792895 tons in 2012 (ANASA, 2012). Despite this production, the country imports an average of 300,000 tons on the international market (CILSS/FAO/MA, 2012). High production costs and low yield due to weed diseases (Naureen et al., 2015), iron toxicity and low fertilizer used are the main causes of low domestic rice production. Despite 
the increase in rice yields during the last decade, they still fall short of producers' expectations (SNSA, 2003). Rice is the staple food of the Guinean population with a national average consumption of $100 \mathrm{~kg}$ per inhabitant per year (SNSA, 2003). Despite the potential available (fertile land, abundant rainfall), iron toxicity is one of the major constraints in the lowlands in Guinea that significantly slows production.

To overcome this scourge, the present study aims to know the effect of silicon on the expression of agro-morphological parameters of rice under iron toxicity conditions. These include: (i) identifying and (ii) selecting rice varieties resistant or tolerant to iron toxicity in lowlands in Guinea; (iii) investigating the effect of silica-variety and variety interaction; (iv) determine the optimum silica dose to be applied for effective control of iron toxicity.

\section{Material and Method Plant material}

The plant material consists of 28 varieties of rice. It is composed of six interspecific lines representing a broad range of sensitivity to iron toxicity developed by the rice center for Africa (Africa Rice Center) in collaboration with the national systems of agronomic research (NARS) of West Africa, sixteen O. glaberrima, one local witness (CK4), one variety will intra specific (ARICA 2), two resistant witnesses (Tog5681, Suakoko8) and two sensitive witnesses (IR64, Bouaké 189) under the conditions of iron toxicity.

\section{Experimental site}

The trial was carried out in Kindia in eastern Lower Guinea (National Monograph, 2000) in the Kilissi Agronomic Research Station (SRAK) (Figure 1) at $9^{\circ} 59$ North latitude and $12^{\circ} 49$ west longitude on a hydromorphic, siltysandy-clay soil. The annual rainfall during the test was $2283.1 \mathrm{~mm}$ for the last 11 months of the year (Figure 2). 


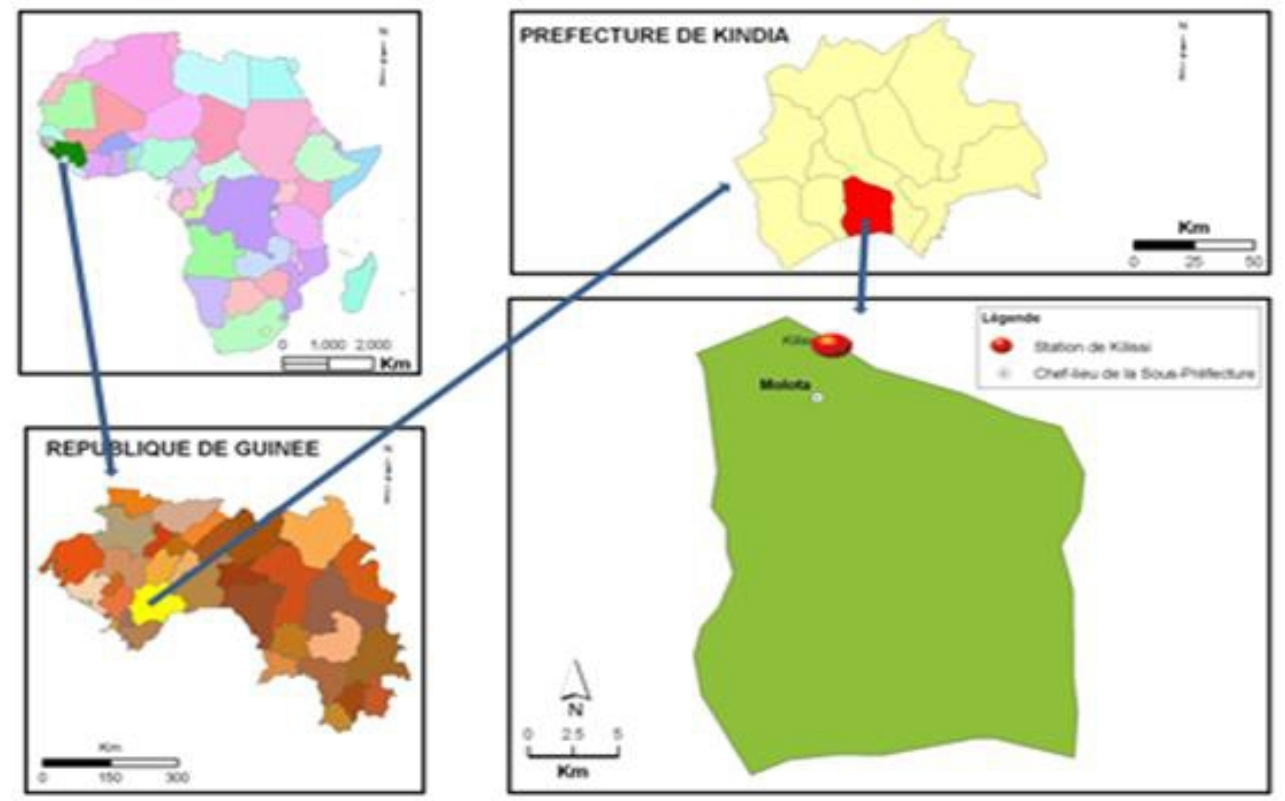

Figure 1: Location of the experimental site

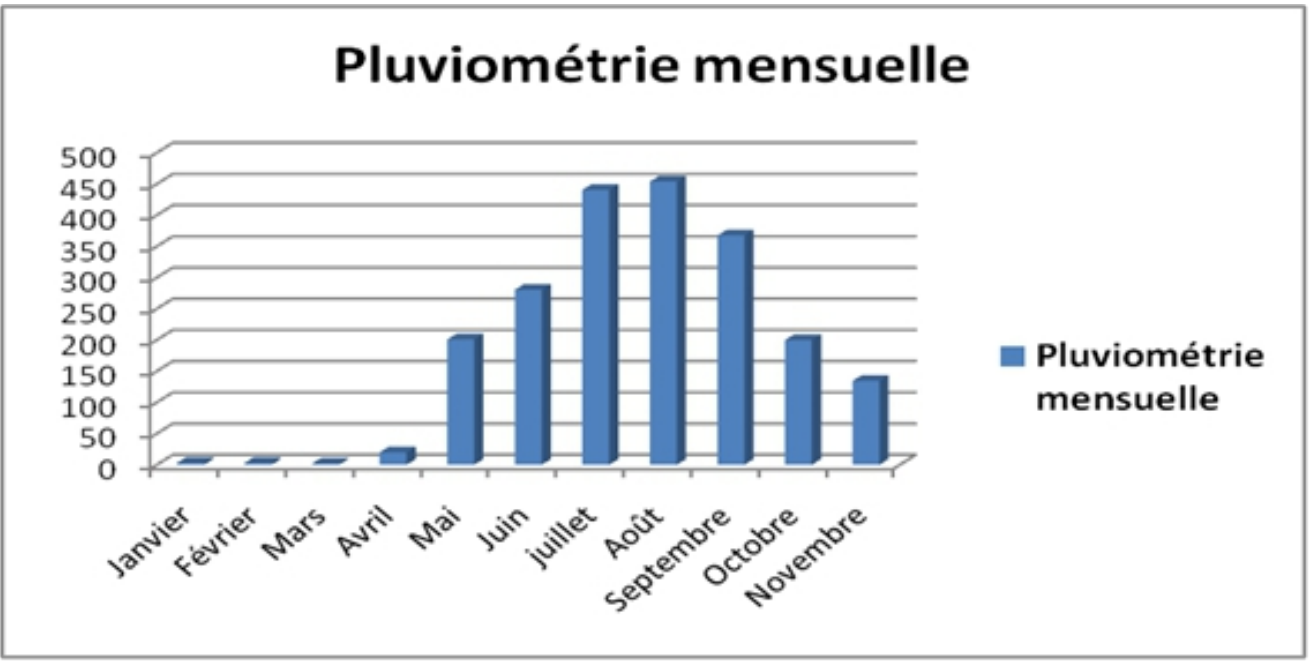

Figure 2: Rainfall distribution during the year 2014

\section{Experimental design and growing conditions}

The trial was implanted following a split plot device with three (3) randomized replications. The distance between the blocks and between the repetitions is $1 \mathrm{~m}$. The area of the basic parcel is $1 \mathrm{~m}^{2}$ with a distance of 0.50 $\mathrm{m}$ between parcels. Each block measures $45 \mathrm{~m}^{2}$, for a total trial area of 900 $\mathrm{m}^{2}$.

The 28 genotypes were put in seedbed on July 7, 2014 and road repair took place on August 03, 2014 of a reason of a bit per seed hole. The 
fertilization consisted of a contribution of manure made up NPK (15-15-15) to the amount of $200 \mathrm{~kg} / \mathrm{ha}$ one week after the road repair of urea $100 \mathrm{~kg} / \mathrm{ha}$ in two spreading at a rate of $35 \mathrm{~kg} / \mathrm{ha}$ at the beginning of tilling and $65 \mathrm{~kg} / \mathrm{ha}$ with panicle initiation. During the test, two manual weeding were carried out. Three amounts of silica D0 (0 g), D120 (120 g) and D240 (240 g) were applied to stolen August 6, 2014 as a granular silica gel according to the method described by (Abed-Ashtiani et al., 2012).

\section{Characters measured}

Quantitative traits used were observed on nine plants per variety. The quantitative characters are:

Humidity content (TH \%) which was determined at the threshold of $14 \%$; plants height measured on the 21st day (HT21JAR) and on the 60th day after transplanting (HT60JAR) and on maturity (HTMat) when 85 to $90 \%$ of the plot has the straw color; the total number of productive tillers at 60 days after transplanting (NTPT) determined by visual counting; number of panicles per plant (NPP) which is the number of fertile tillers at maturity; total number of grains per panicle (NGPI) corresponding to the total number of grains per panicle that is evaluated on a panicle per plant taken from the 9 plants of each variety; the number of grains per panicle which corresponding to total number of grains given by panicle; the grain yield (Rdmt). Parcel yield was obtained by harvesting each plot when $85-90 \%$ of the panicles are mature. Then, the panicles are beaten, dried, winnowed and yields determined at 14\% humidity. The yield per hectare is obtained by extrapolating the plot yield. The variation of yield of the amounts D120 (ER1) and D240 (ER2) compared to the pilot amount (D0) was estimated by making the difference between the yield obtained in each one of these two amounts and the D0 amount. The rate of variation was calculated according to the formula TVR $(\%)=\frac{\text { E1ouE2 }}{\text { D0 }} \times 100$. The 1000 grains weight (P1000G) evaluated using a precision balance; sowing-heading cycle (CSE) represents the number of days between sowing and heading.

\section{Data analysis}

The Excel 2010 sofware was used for data entry and graph construction. In order to test the effect of silica, varieties and their interaction on different agronomic parameters, an analysis of variance (ANOVA) according to a linear model and the Newman-Keuls test at the $\alpha$ threshold of 5\% and of 1\% have were made with Genstat software version 2014. 


\section{Results and Discussion Effect of treatments on measured traits}

The growth and development of rice are affected by iron toxicity. In addition, there was either an increase or a decrease in height depending on the doses and varieties at different stages of development of the rice plants. All measured plant traits showed a decrease

The results of the analysis of variance consigned in table 1 shows that except the plant height at maturity and the humidity content, the other characters were very significantly influenced by silica $(\mathrm{P}<0.001)$. On the level of the varieties, all the parameters were very influenced by silica $(\mathrm{P}<0.001)$. The interaction varieties $\mathrm{x}$ blocks influenced significantly the characters such as number of grains per panicle, number of full grains, number of productive tillers, weight of 1000 grains, number of panicles per plant and grains yield. Prior studies revealed also an important variability within local varieties in others country (Barry, 2006; Gaouna, 2011, 2012).

An analysis of the composition of the groups resulting from the Hierarchical Ascending Classification (CAH) according to the different doses of silica reveals that the varieties Arica1, Arica2, Arica3, Azucena, Tog5421, CK4, Nerica L19, Nerica 20, WITA9 are the most stable. Indeed, these varieties presented the best agronomic characteristics according to the different doses of silica applied.

Table 1: Effect of treatments on measured traits.

\begin{tabular}{lllllll}
\hline \multirow{2}{*}{ Traits } & $\begin{array}{l}\text { Source } \\
\text { variation }\end{array}$ & Blocks & Variéties & Blocks* Varieties & CV (\%) & PPDS \\
\cline { 2 - 5 } & d.f. & 2 & 28 & 54 & & \\
\hline CSE & F pr. & $0,02^{*}$ & $<.001^{* *}$ & $1^{\mathrm{NS}}$ & 4,1 & 1,68 \\
HT21JAR & F pr. & $0,002^{* *}$ & $<.001^{* *}$ & $0,011^{*}$ & 17,8 & 10,74 \\
HT60JAR & F pr. & $<.001^{* *}$ & $<.001^{* *}$ & $0,296^{\mathrm{NS}}$ & 13,3 & 6,56 \\
HTMat & F pr. & $0,175^{\mathrm{NS}}$ & $<.001^{* *}$ & $0,346^{\mathrm{NS}}$ & 13,4 & 5,26 \\
NGP & F pr. & $<.001^{* *}$ & $<.001^{* *}$ & $<.001^{* *}$ & 9,6 & 6,7 \\
NGP1 & F pr. & $<.001^{* *}$ & $<.001^{* *}$ & $<.001^{* *}$ & 11,1 & 6,7 \\
NPP & F pr. & $<.001^{* *}$ & $<.001^{* *}$ & $<.001^{* *}$ & 17,7 & 0,85 \\
NTPT & F pr. & $<.001^{* *}$ & $<.001^{* *}$ & $<.001^{* *}$ & 14,8 & 1,37 \\
P1000G & F pr. & $0,031^{*}$ & $<.001^{* *}$ & $0,056^{*}$ & 11,7 & 2,92 \\
Rdmt & F pr. & $<.001^{* *}$ & $<.001^{* *}$ & $<.001^{* *}$ & 13,5 & 0,33 \\
TH $(\%)$ & F pr. & $0,113^{\mathrm{NS}}$ & $<.001^{* *}$ & $0,185^{\mathrm{NS}}$ & 5 & 0,85 \\
\hline
\end{tabular}

Legend : CSE: cycle sowing-heading, HT21JAR: plant height at 21 day after transplanting, HT60JAR: height at 60 day after transplanting, HTMat: plant height at maturity, NGP:number of grains per panicle, NGPl: number of full grains, NPP :number of panicle per plant , NTPT : number of productive tillers at 60 days after transplanting, P1000G: weight of 1000 grains, Rdmt: grains yield, TH: Humidity content. 


\section{Effect of silica dose on grains yield}

The results of the analysis of variance reported in Table 2 reveal an influence of silica doses on grain yield up to $6.9 \mathrm{t} /$ ha with Tog6080. Indeed, in addition to the variability observed between the accessions tested for each dose, a significant effect of the silica doses on the yield is also observed. However, at each dose, the coefficients of variation are relatively low $(<20 \%)$. The variations in yield of the varieties presented in Figure 3 show that the paddy yields of the tested varieties change according to the doses of silica applied and the varieties of rice tested. The lowest yield was obtained by the Tog7105 variety with the control treatment (D0) $(1.4 \mathrm{t} / \mathrm{ha})$ and the best yield is recorded by the Tog 6080 variety with the D240 treatment (6.9 t/ha). Similar results are reported by (Gheysens \& Bertin 2009) who showed an important effect of silica on iron expression on rice yield.

Table 2: Effect of silica application on grains yield

\begin{tabular}{|c|c|c|c|c|}
\hline \multirow[b]{2}{*}{ Varieties } & \multicolumn{3}{|c|}{ Dose } & \multirow[b]{2}{*}{ D $240(\mathrm{~g})$} \\
\hline & Status & D $0(g)$ & D $120(\mathrm{~g})$ & \\
\hline Suakoko 8 & TR & $3.020 \mathrm{Bf}$ & $3.467 \mathrm{Af}$ & $4.393 \mathrm{Afg}$ \\
\hline Tog5681 & TR & - & - & - \\
\hline Bouaké 189 & TS & $2.889 \mathrm{Cfg}$ & $3.900 \mathrm{Be}$ & $4.667 \mathrm{Af}$ \\
\hline IR64 & TS & $2.103 \mathrm{Ch}$ & 3.633 Bef & $4.492 \mathrm{Af}$ \\
\hline ARICA 1 & VT & $3.758 \mathrm{Bd}$ & $3.681 \mathrm{Bef}$ & $5.167 \mathrm{Ae}$ \\
\hline ARICA 2 & VT & $4.556 \mathrm{Cb}$ & $5.107 \mathrm{Bbc}$ & 6.600 Aab \\
\hline ARICA 3 & VT & 4.800 Bab & $5.100 \mathrm{Abc}$ & 5.324 Ade \\
\hline Azucena & VT & $4.267 \mathrm{Cbc}$ & $5.100 \mathrm{Bbc}$ & $5.533 \mathrm{Ad}$ \\
\hline CK4 & VT & $4.727 \mathrm{Cab}$ & $5.407 \mathrm{Bb}$ & $6.667 \mathrm{Aab}$ \\
\hline Nerica 19 & VT & 4.800 Aab & $4.753 \mathrm{Ac}$ & $4.093 \mathrm{Bg}$ \\
\hline Nerica 20 & VT & $4.312 \mathrm{Cbc}$ & $6.000 \mathrm{Aa}$ & $5.133 \mathrm{Be}$ \\
\hline Tog 14349 & VT & $4.567 \mathrm{Cb}$ & $5.333 \mathrm{Bb}$ & $6.433 \mathrm{Ab}$ \\
\hline Tog5421 & VT & $4.111 \mathrm{Cc}$ & $5.333 \mathrm{Bb}$ & $6.333 \mathrm{Ab}$ \\
\hline $\operatorname{Tog} 5440$ & VT & $2.557 \mathrm{Cg}$ & $5.327 \mathrm{Ab}$ & $4.353 \mathrm{Bfg}$ \\
\hline Tog5541 & VT & $3.021 \mathrm{Cf}$ & $5.403 \mathrm{Bb}$ & $5.998 \mathrm{Ac}$ \\
\hline Tog5672 & VT & $2.431 \mathrm{Cgh}$ & $2.891 \mathrm{Bg}$ & $3.900 \mathrm{Ag}$ \\
\hline Tog5674 & VT & $4.271 \mathrm{Abc}$ & - & - \\
\hline Tog5810 & VT & $3.373 \mathrm{Ce}$ & $4.933 \mathrm{Bc}$ & $6.367 \mathrm{Ab}$ \\
\hline Tog5923 & VT & $1.878 \mathrm{Bh}$ & $1.954 \mathrm{Bh}$ & $4.361 \mathrm{Afg}$ \\
\hline Tog6080 & VT & 3.333 Cef & $4.367 \mathrm{Bd}$ & $6.900 \mathrm{Aa}$ \\
\hline Tog6523 & VT & $4.912 \mathrm{Ba}$ & $6.233 \mathrm{Aa}$ & $6.412 \mathrm{Ab}$ \\
\hline Tog7105 & VT & 1.418 Bi & $2.776 \mathrm{Ag}$ & $2.907 \mathrm{Ai}$ \\
\hline Tog7291 & VT & $4.033 \mathrm{Ccd}$ & $4.608 \mathrm{Bcd}$ & $5.907 \mathrm{Ac}$ \\
\hline Tog7449 & VT & $3.486 \mathrm{Cde}$ & $5.975 \mathrm{Ba}$ & $6.667 \mathrm{Aab}$ \\
\hline Tog7975 & VT & $2.833 \mathrm{Bfg}$ & $3.505 \mathrm{Af}$ & $3.833 \mathrm{Agh}$ \\
\hline Tog9332 & VT & $2.330 \mathrm{Cgh}$ & $3.039 \mathrm{Bg}$ & $3.539 \mathrm{Ah}$ \\
\hline WAT1046-B-43-2-2-2: (Arica) & VT & 2.307 Agh & $2.286 \mathrm{Ah}$ & $2.567 \mathrm{Aj}$ \\
\hline WITA 9 & VT & $4.033 \mathrm{Ccd}$ & $5.433 \mathrm{Bb}$ & $6.267 \mathrm{Abc}$ \\
\hline Mean & & 3.455 & 4.444 & 6.267 \\
\hline LSD $5 \%$ & & 0.3344 & 1,45 & 1,84 \\
\hline CV\% & & 4.52 & 6,8 & 12,5 \\
\hline
\end{tabular}


Legend: assigned means of the same letter in the same column or line are not significantly different at the 5\% threshold by calculating the PPDS. The upper case letters are attached to the lines and the lower case letters to columns. D0 $=0 \mathrm{~g} / \mathrm{m} 2$ silica, D $120=120 \mathrm{~g} / \mathrm{m} 2$ silica, D240 $=240 \mathrm{~g} / \mathrm{m} 2$ silica, TR: Resistant controls, TS: Sensible indicators, VT: Varieties tested, $\mathrm{CV}$ : coefficient of variation, LSD: little significant difference

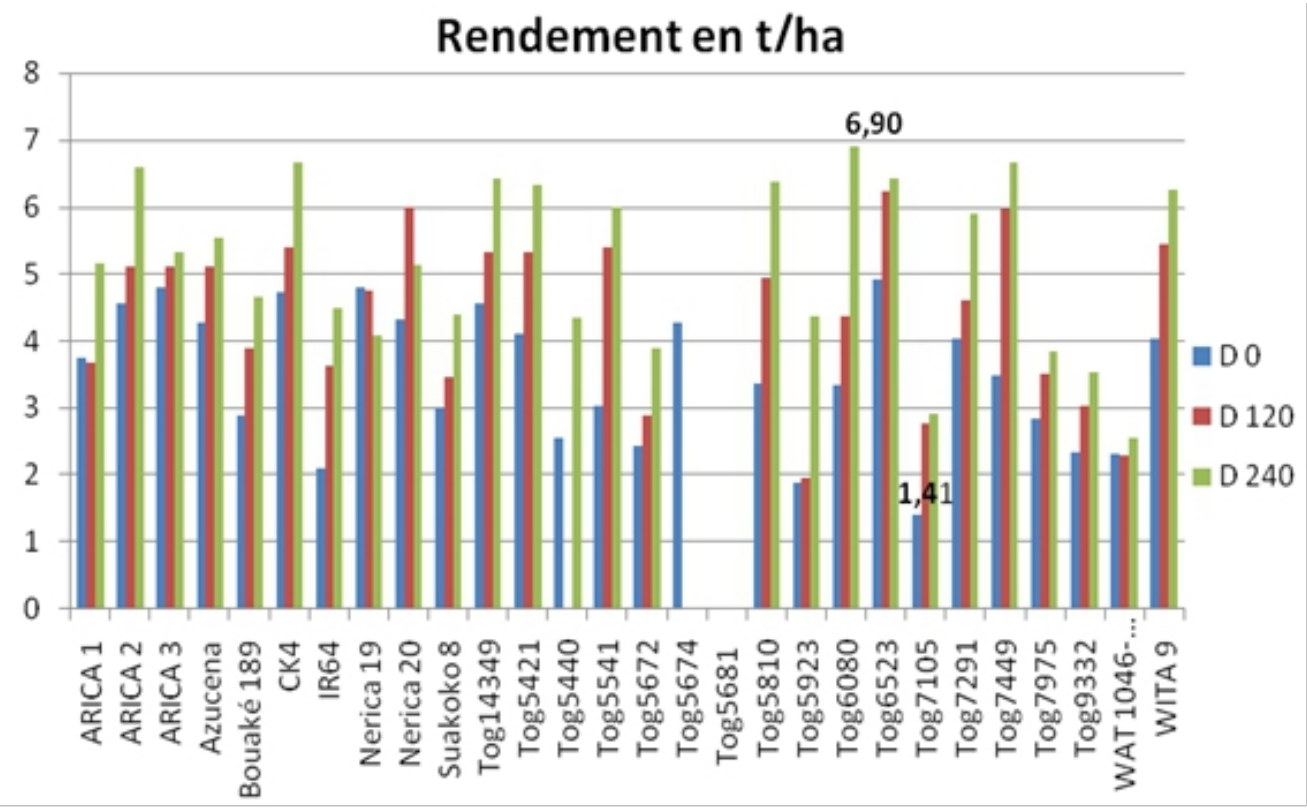

Figure 3: Variation in grains yield of varieties for different doses of silica $D 0=0 \mathrm{~g} / \mathrm{m}^{2}$ de silice, $D 120=120 \mathrm{~g} / \mathrm{m}^{2}$ de silice, $D 240=240 \mathrm{~g} / \mathrm{m}^{2}$ de silice

\section{Comparison of grains yields of varieties according silica doses}

Comparison of yields (Table 3) reveals an important difference in grains yield of varieties that was observed between the three doses of silica. Except the two varieties (Nerica19, WAT 1046-B-43-2-2-2: (Arica) which showed a reduction in yield with both doses silica and ARICA 1 showing a decrease in yield only with the dose D120, the other varieties showed a gradual increase in yield as a function of the doses. Indeed, the yield increase varies from 0.076 to $2.77 \mathrm{t} / \mathrm{ha}$ for D120 dose and 0.26 to $3.56 \mathrm{t} / \mathrm{ha}$ for D240 dose corresponding respectively to rates of $4.04 \%$ to $108 \%$ and $11.27 \%$ to $107 \%$. In the varieties that gave the best grain yields; the progress is $31 \%$ for D120 and $107 \%$ for D240 with Tog6080, $12.9 \%$ for D120 and $44.8 \%$ for D240 with Arica $2,19.52 \%$ for dose D120 and $29.66 \%$ for the dose D240 with the variety Azucena, $14.3 \%$ for the dose D120 and $41 \%$ for the dose D240 with the variety CK4, 26.89\% for the dose D120 and 30.5\% for dose D240 with the Tog6523 variety and $6.25 \%$ for the D120 dose and $10.9 \%$ for the D240 dose with the Arica 3 variety. The most stable variety is Arica 3, which has a variation of $6.25 \%$ for D120 and $10.9 \%$ for D240. 
Yields vary according to the degree of toxicity of the varieties tested. All varieties have a significantly lower yield under iron toxicity stress. The iron toxicity stress induced a yield loss of $0.988 \mathrm{t} /$ ha compared to the D120 and 1.729 t/ha compared to the D240 dose, corresponding to a $28.58 \%$ and $50 \%$ decrease in potential yield, respectively. (Audebert, 2006). for its part found a yield reduction of $43 \%$. Aboa and Dobé (2006) reported a loss of $59.5 \%$. According to Tamaung (2006), the decline in rice yields varies from 12 to $100 \%$ in West Africa under conditions of iron toxicity. For all these characteristics, the effectiveness of the doses on the reduction of the toxicity can be staggered as follows: D240g> D120> D0.

The growth and development of rice are affected by iron toxicity. Moreover, it has been found either an increase or a decrease in the height according to the doses and the varieties at different stages of development of the rice plants. The significant decrease in the performance of all traits with the exception of the semi-emergence cycle of plants measured between D0 and D120, D240 is similar to the previous results of Gheysens and Bertin (2009), and this could be explained by the influence of D120 and D240 doses of silica on these different characters studied. Indeed, the semi-seasoning cycle increased between 1 and 7 days according to the varieties except for the varieties Tog5421 and Tog5672 where a decrease of 1 to 3 days was rather according to the doses of silica, this result corroborates that obtained by Audebert (2006). The cycle time of the varieties tested was affected by the different doses of silica. It was longer with the D240 dose.

The number of panicles per tuft varies according to silica doses and varieties. In fact, the average panicle number varied from 4.95 with the D0 dose to 19.33 with the D240 dose. According to Tamaung (2006), the iron absorbed by the rice plants is concentrated in the leaves and causes discoloration of the limbs and leads to a sharp reduction in tilling and the height of the rice plants.

The contribution of silica both allows minimizing the toxic effect of excess iron on grain yield of rice. The application of a $240 \mathrm{~g}$ dose of silica on a culture under conditions of iron toxicity has made it possible to increase rice production. These results are similar to those obtained by Aboa and Dobé (2006) in their study on the effect of iron toxicity on rice yield in the AmouOblo lowland in Togo. Many tolerant varieties had been identified (Camara, 2006). Some of its varieties give better yields. Prior Investigations carried out (Sié et al., 2010) have shown that iron toxicity is one of the factors that limit yields, especially in the shallows, by inhibiting plant growth and root development, which influences the absorption and retention of nutrients. This drop in yields shows the depressive effect of iron toxicity on rice production in the lowlands. 
Table 3: Recorded performance gap and rate of change in dose yield relative to D0

\begin{tabular}{lllll}
\hline \multirow{2}{*}{ Varieties } & \multicolumn{2}{l}{ Yield difference (t/ha) } & \multicolumn{2}{c}{ Variation rate $\mathbf{( \% )}$} \\
\cline { 2 - 5 } & ER1 & ER2 & TVR1 & TVR2 \\
\hline ARICA 1 & -0.077 & 1.409 & -2.04 & 37.49 \\
ARICA 2 & 0.551 & 2.044 & 12.09 & 44.86 \\
ARICA 3 & 0.3 & 0.524 & 6.25 & 10.91 \\
Azucena & 0.833 & 1.266 & 19.52 & 29.66 \\
Bouaké 189 & 1.011 & 1.778 & 34.99 & 61.54 \\
CK4 & 0.68 & 1.94 & 14.38 & 41.04 \\
IR64 & 1.53 & 2.389 & 72.75 & 113.59 \\
Nerica 19 & -0.047 & -0.707 & -0.97 & -14.72 \\
Nerica 20 & 1.688 & 0.821 & 39.14 & 19.03 \\
Suakoko 8 & 0.447 & 1.373 & 14.80 & 45.46 \\
\hline Tog14349 & 0.766 & 1.866 & 16.77 & 40.85 \\
Tog5421 & 1.222 & 2.222 & 29.72 & 54.05 \\
Tog5440 & $\mathbf{2 . 7 7}$ & 1.796 & $\mathbf{1 0 8 . 3 3}$ & 70.23 \\
Tog5541 & 2.382 & 2.977 & 78.84 & 98.54 \\
Tog5672 & 0.46 & 1.469 & 18.92 & 60.42 \\
Tog5810 & 1.56 & 2.994 & 46.24 & 88.76 \\
Tog5923 & $\mathbf{0 . 0 7 6}$ & 2.483 & $\mathbf{4 . 0 4}$ & 12.21 \\
Tog6080 & 1.034 & $\mathbf{3 . 5 6 7}$ & 31.02 & $\mathbf{1 0 7 . 0 2}$ \\
Tog6523 & 1.321 & 1.5 & 26.89 & 30.53 \\
Tog7105 & 1.358 & 1.489 & 95.76 & 105.00 \\
Tog7291 & 0.575 & 1.874 & 14.25 & 46.46 \\
Tog7449 & 2.489 & 3.181 & 71.39 & 91.25 \\
Tog7975 & 0.672 & 1 & 23.72 & 35.29 \\
Tog9332 & 0.709 & 1.209 & 30.42 & 51.88 \\
\hline WAT 1046-B-43-2-2-2: (Arica) & -0.021 & $\mathbf{0 . 2 6}$ & -0.91 & 11.27 \\
WITA 9 & 1.4 & 2.234 & 34.71 & 55.39 \\
\hline Mean & $\mathbf{0 . 9 8 8}$ & $\mathbf{1 . 7 2 9}$ & $\mathbf{2 8 . 5 8}$ & $\mathbf{5 0 . 0 3}$ \\
\hline & & & &
\end{tabular}

\section{Conclusion}

The search for rice varieties resistant to iron toxicity is therefore a continuous operation that requires complementary actions from several disciplines and a lot of investment. From this study, it is clear that a buffer effect of silica on the ferrous toxicity of rice and a significant influence of silica on several important agronomic parameters such as grains yield. The dose of $240 \mathrm{~g}$ of silica makes it possible to obtain the highest yields.

Seventeen (17) varieties of the 28 varieties are likely to provide a high yield with good resistance or tolerance to iron toxicity. The genetic variability observed with certain tolerant varieties with ferrous toxicity like CK4 could be exploited in our national rice breeding program. 


\section{Acknowledgements}

The authors gratefully acknowledge the financial support provided by «Institut de Recherche Agronomique de Guinée (IRAG) ». Thanks also to all members of «Laboratoire Biosciences » of «Université Ouaga 1 Pr Joseph $\mathrm{KI}-\mathrm{ZERBO} \gg$ for the reading and correction of manuscript.

\section{Conflict of interests}

The authors have not declared any conflict of interests.

\section{References:}

1. Abed-Ashtiani, F., Kadir, J., Selamat, A., Mohd-Hanif, A. H., \& Nasehi, A. (2012). Effect of foliar and root application of silicon against rice blast fungus in MR219 rice variety. In The Plant Pathology Journal,: 28: 164-171.

2. Aboa, K. \& Dogbe, S. Y. (2006). Effect of iron toxicity on rice yield in the Amou-Oblo lowland in Togo. Iron Toxicity in Rice-based Systems in West Africa (2006) 1.

3. AFRICA RICE (2013). La science rizicole pour la sécurité alimentaire à travers le renforcement de l'agriculture familiale et l'agro-industrie en Afrique, $3^{\text {ème }}$ Congrès du riz en Afrique, 21-24 Octobre 2013, Yaoundé (Cameroun), 296p.

4. ANASA (2012). Agence Nationale des Statistiques Agricoles et Alimentaires. Rapport synthèse, Conakry, République de Guinée, 11p,

5. CILSS/FAO/MA, 2012. Rapport Conjoint pour l'évaluation finale de la campagne agricole en Guinée, Conakry, République de Guinée, 43p.

6. Audebert, A. (2006). Répartition du fer comme mécanisme de tolérance à la toxicité ferreuse en riziculture de bas-fond. CIRAD-CA UPR Riziculture, Montpellier, France In: ADRAO, 35p.

7. Barry, M. B. (2006). Diversité et dynamiques des variétés locales de riz (O. sativa\& O. glaberima) en Guinée, Conséquences pour la conservation des ressources génétiques, Thèse de Doctorat, Ecole nationale supérieure agronomique de Rennes, France, 158p.

8. Camara, A. K. (2006). Testing and developing tolerant rice varieties to iron toxicity in lower guinea (CRA kilissi and koba). "Iron Toxicity in Rice-based Systems in West Africa (2006): 64.

9. CIRAD (2010). Spécificités des filières riz dans le monde. ENITA de Bordeaux, 79p.

10. CTA (2013). Secteur du riz. Post bus 3806700, AJ Wageningen, PaysBas. 12p.

11. FAO (2007). Elaboration d'un programme d'assistance technique pour les pays de l'Afrique de l'ouest. Rapport pays - République de Guinée, Conakry, 217p, 
12. FAO STAT (2011). World Rice Production 2009-2010,.Visit le 15/12/2017. www.fao.org

13. Futakuchi, K., Sié, M. \& Wopereis, M. C. S. (2011). Rice breeding strategy at Africa Rice. In: S. Yanagihara (Ed.). Next Challenges in Rice Development for Africa: Workshop for New Collaboration between JIRCAS and Africa Rice,: 1-14.

14. Gaouna, B. O., Oueye, M. B., Nanema, K. R., Naoura, G. \& Zongo, J. D. (2011). Agromorphological characterization of some rice species in the main rice cropping area of Chad. In International Journal of Biological and Chemical. Sciences 5(2): 445-460.

15. Gaouna, B. O., Traoré, R. E., Assane, S. \& Zongo, J. D. (2012). Caractérisation agromorphologique des accessions de riz adventices (Oryza $s p$ ) collectés dans les rizières de la zone interfluve du Tchad. In International Journal Of Biological and Chemical. Sciences 5(6): 1774-1791.

16. Gheysens, S. \&Bertin, P. (2009). Impact du silicium sur l'expression de la toxicité ferreuse chez le riz Cultivé (Oryza sativa L.). Mém. présenté en vue de l'obtention du grade de Bio-ingénieur. Université Catholique de Louvain. Faculté d'ingénierie biologique, Agronomique et environnementale. $100 \mathrm{p}$.

17. Houssou, A. F. P, Tchatcha, D., Mensah, A.G., Kabore, A., Futakuchi, K., Traore, K., Moreira, J. \& Diagne, A. (2016). Suitability For Parboiling Of Rice Varieties From Benin Through Assessing The Soaking Temperature And Rice Quality In European Scientific Journal 12 (21) : 144-158.

18. IFDC (2011). Fiche d'information, publication conjointe du Projet MIR Plus et l'Initiative PPU/SAADA menée par le Programme de Gestion des Ressources Naturelles de l'IFDC. Fiche d'information, N]6, octobre 2011, IFDC, Ouagadougou, Burkina Faso, 4p,

19. Kuri, S. K., Hossain, M. J. \& Mondal, U. (2014). Rice for nutrition: a temporal perspective of the major saarc countries. In European Scientific Journal 10 (12) : 502-512.

20. Naureen, Z., Hafeez, F. Y., Hussain, J., Harrasi, A. A., Bouqellah, N., Roberts, M.R. (2015). Suppression of incidence of Rhizoctonia solani in rice by siderophore producing rhizobacterial strains based on competition for iron. In European Scientific Journal 11 (03) : 186-207.

21. Sié, M., Saito, K., Kone, B., Chabi, A., Dakouo, D., Annan-Afful, E., Monh, S., Abo, E. \& Dramé, K. N. (2010). Coping with iron toxicity in the lowlands of sub-Saharan Africa: Experience from Africa Rice Center. Second Africa Rice Congress, Bamako, Mali, 22-26 March 2010: Innovation and Partnerships to Realize Africa's Rice Potential. $8 \mathrm{p}$, 
22. SNSA (2003). Service National des statistiques Agricoles, Rapport national, Conakry, 2010, République de Guinée, 11p,

23. Tamaung, M. (2006). Physiological mechanisms of iron toxicity tolerance in lowland rice. Thesis in partial fulfillment of the requirements for the academic degree of Master of Science. Faculty of Agriculture Rheinische Friedrich-Wilhelm's Universitätzu Bonn, $.67 \mathrm{p}$.

24. Worou, O. N., Gaiser, T., Igué, M. A., Gbemavo, C. \& Sinsin, B. A. (2017). Responses of Upland NERICA Rice to Fertiliser Application and Fallow Management in Different Agro-Ecological Zones of Benin Republic. In European Scientific Journal 13 (27) : 152-170. 